\title{
Local Recurrence after Treatment of Ductal Carcinoma In Situ: A Comprehensive Overview
}

\author{
Amelia Chiorescu ${ }^{1,2^{*}}$, Hanna Fredholm ${ }^{1,2}$, Helena Ikonomidis Sackey ${ }^{1,2}$, Irma Fredriksson ${ }^{1,2}$ \\ 'Department of Molecular Medicine and Surgery, Karolinska Institutet, Stockholm, Sweden \\ ${ }^{2}$ Department of Breast, Endocrine tumors and Sarcoma Surgery, Karolinska University Hospital, Stockholm, Sweden
}

*Corresponding author: Amelia Chiorescu, MD Department of Molecular Medicine and Surgery, Karolinska Institutet Stockholm, Sweden E-Mail: amelia.chiorescu@ki.se

\section{Rezumat}

Pacientele cu carcinom ductal in situ (CDIS) au un prognostic excelent pe termen lung, cu o rată de supraviețuire la 10 ani specifică cancerului de sân de cca. 98\%. Scopul tratamentului este de acela de a preveni apariția cancerului de sân invaziv şi de a minimiza riscul recidivei neoplasmului mamar, lucru reflectat în studiile publicate, care arată o reducere substanțială a recidivei locale de tip invaziv de-a lungul timpului. Aproximativ 50\% din recidivele locale ce au loc după chirurgia conservatoare a sânului (CCS) sunt de tip invaziv, iar 8,5\% din cazuri includ invazie ganglionară. O recidivă ipsilaterală de tip invaziv după CDIS creşte semnificativ riscul de deces prin neoplasm mamar, acest lucru nefiind întâlnit în recidivele de tip CDIS. Chirurgia radicală rămâne esențială în minimizarea riscului de recidivă locală, iar radioterapia adjuvantă reduce riscul apariției recidivei locale cu cel puțin $50 \%$. In caz de recidivă se poate opta pentru o reintervenție chirurgicală de conservare a sânului (CCS), întrucât conferă un control adecvat în cazuri atent selecționate şi o rată de supraviețuire generală cât şi specifică neoplasmului mamar comparabilă cu cea post mastectomie.

Cuvinte cheie: sân, carcinom ductal in situ, recidivă locală, factori de risc, chirurgie de salvare, prognostic

\section{Abstract}

Patients with DCIS have an excellent long-term prognosis with a 
10-year breast cancer-specific survival around 98\%. Treatment has the goal to prevent the development of an invasive breast cancer and to minimize the risk for a second breast cancer event, and published studies have shown a substantial decrease in invasive local recurrence rates over time. Approximately 50\% of the local recurrences after BCS for a primary DCIS are invasive and 8.5\% of them node-positive. Experiencing an ipsilateral invasive recurrence after a primary DCIS does significantly increase the risk of breast cancer death, while this is not seen after a DCIS recurrence. Radical surgery remains crucial to minimize the risk of local recurrence, and adjuvant radiotherapy reduces the risk of local recurrence by at least $50 \%$. At recurrence, a repeat-BCS should be considered as it offers a good local control in properly selected patients and an overall and breast cancer-specific survival comparable to that seen after mastectomy.

Key words: breast, ductal carcinoma in situ, local recurrence, risk factors, salvage surgery, prognosis

\section{Introduction}

Ductal carcinoma in situ (DCIS) accounts for approximately one fifth of all newly diagnosed breast cancers but with considerable variation in incidence among countries, with the lowest proportion noted in Finland (9 \%; $95 \%$ CI: 8-10\%) and the highest in the US (24\%; $95 \%$ CI: $22-25 \%)$ (1). Generally, patients with DCIS have an excellent long-term prognosis with a 10-year breast cancer-specific survival around 98\% (2-4). Treatment has the goal to prevent the development of an invasive breast cancer, to minimize the risk for a second breast cancer event and with as little effect as possible on the patient's quality of life. Experiencing an ipsilateral invasive recurrence after a primary DCIS increases the risk of breast cancer death 18 -fold while this is not seen after a DCIS recurrence $(4,5)$.

The aim of this review was to provide an updated overview of current knowledge on local recurrence after primary treatment of DCIS focusing on risk factors for local recurrence, characteristics and optimal treatment of local recurrence as well as prognosis after local recurrence.

\section{Definition of Local Recurrence versus New Primary}

Local recurrence is defined as the reappearance of cancer, invasive or in situ, in the ipsilateral preserved breast or the chest wall following mastectomy. A local recurrence may represent a true recurrence arising from the original tumor (treatment failure), or a new primary (de novo carcinogenesis), and establishing this distinction remains a challenge. There is no universally accepted method to distinguish them although anatomic distance from the original primary, time since primary tumor, concordance of histology and subtype, analysis of comparative genomic hybridization, genomewide copy number and loss of heterozygosity have been used, all with variable reliability $(6-8)$. The distinction between recurrences and de novo lesions will likely get better with advances in molecular diagnostics (9).

\section{Primary Treatment and Incidence of Local Recurrence}

The major treatment options for DCIS include breast-conserving surgery (BCS), breastconserving surgery and radiotherapy (BCS+ RT) and mastectomy. A large retrospective study based on the National Cancer Institute's Surveillance, Epidemiology, and End Results (SEER) registry (http://seer.cancer.gov/), showed no clinically relevant difference in 10-year breast cancer-specific survival between women treated with BCS+RT versus mastectomy (2). Randomized trials and a metaanalysis have shown that radiotherapy after BCS reduces the risk of local recurrence by at 
least 50\% compared to BCS alone, and with similar effects in reducing ipsilateral in situ and invasive recurrences, but with no significant effect on overall or breast cancerspecific survival (10-14). Further reduction in recurrence rates has also been observed following the addition of endocrine treatment to $\mathrm{BCS}+\mathrm{RT}$ in estrogen receptor (ER)-positive DCIS $(15,16)$. However, no survival benefit has been proven (17) and therefore treatment in each case needs to be considered with a thorough risk-benefit analysis.

In an overview of the EBCTCG trials, including data from 4 randomized studies comparing $\mathrm{RT}$ versus no RT following BCS, the 10-year risk of an ipsilateral local recurrence, DCIS or invasive, was $12.9 \%$ after BCS+RT and $28.1 \%$ after BCS only (13), with no heterogeneity between the trials. In a meta-analysis of 5 prospective (4 randomized) and 21 retrospective studies, the risk of local recurrence after mastectomy for a primary DCIS was $2.6 \%$ at 10 year follow up, while the corresponding risk after BCS+RT was $13.6 \%$ and after BCS only 25.5\% (18). The risk of invasive local recurrence was $2.5 \%$ after mastectomy, $7.4 \%$ after BCS+RT and 11\% after BCS only. In studies where DCIS treatment was not randomized, the choice of therapy might have been related to risk of developing invasive recurrence, introducing bias and a risk of underestimation of the true difference in risk between treatments. In a national population-based Dutch study the cumulative incidence of invasive recurrence at 15 years was $1.9 \%$ after mastectomy, $8.8 \%$ after BCS+RT and $15.4 \%$ after BCS alone, which can be compared to a 15-year cumulative risk of contralateral invasive breast cancer of $6.4 \%$, not differing by treatment (19).

Several studies, both observational and randomized trials, have shown a substantial decrease in invasive local recurrence rates over time (19-21), while the risk of contralateral invasive breast cancer has remained unchanged (19). The decrease in local recurrence rates has been explained by improved radiological detection leading to a larger proportion of relatively harmless lesions, better preoperative assessment of tumor extent, better surgical management (negative margins) (19) and increased use of endocrine therapy.

\section{Characteristics of Local Recurrences after a Primary DCIS}

Approximately $50 \%$ of the local recurrences after BCS are invasive $(6,22,23)$, and $8.5 \%$ of them node-positive (22), whereas most recurrences after mastectomy are invasive $(24,25)$. Annual mammography is not recommended after mastectomy followed by reconstruction, and not feasible after simple mastectomy. Accordingly, most recurrences after mastectomy gets diagnosed after becoming palpable or involving the skin (26). Median time to invasive recurrence has not been shown to differ by treatment (BCS 6.4 years versus mastectomy 5.5 years, $\mathrm{p}=0.12$ ) (26). Most invasive recurrences after mastectomy are seen in women with high-risk characteristics at primary diagnosis, such as young age, highgrade DCIS with necrosis and multifocal/ multicentric disease, whereas this association is less clear after BCS (26).

\section{Risk Factors for Local Recurrence after Primary Treatment for DCIS}

A large number of publications have established several risk factors that contribute to increased risk of recurrence after primary treatment for DCIS (23,24,27-29), including both patient-related factors, pathological risk factors and factors related to treatment (Table 1).

Randomized studies, meta-analyses and observational studies have consistently shown that young women have a more than 2 -fold risk of local recurrence, both invasive and intraductal $(5,10,13,23,24,30,31)$. This higher risk has been proposed to be due to a higher proportion of DCIS with poor prognostic features like high-grade and multifocality, and a higher proportion of symptomatic disease (32).

Conversely, the increased risk of local 
Table 1. Risk factors for local recurrence after primary treatment of ductal carcinoma in situ

\begin{tabular}{l}
\hline Patient related risk factors \\
- young age \\
Tumor detection mode \\
(symptomatic disease versus screening-detected) \\
\hline Pathological risk factors \\
- large tumor extent \\
- high nuclear grade \\
- comedo necrosis \\
- multifocality/multicentricity \\
- microcalcifications \\
- microinvasion \\
- molecular subtype (HER2 versus Luminal A) \\
- biomarker expression (Ki67 high, HER2+) \\
- high Oncotype DX DCIS Score \\
Treatment related risk factors \\
- positive or close surgical margins \\
- type of surgery \\
(BCS/skin-sparing mastectomy versus mastectomy) \\
- no radiotherapy after BCS \\
- no endocrine therapy \\
\hline
\end{tabular}

recurrence seen in symptomatic disease $(23,28,33)$ has been suggested to be due to confounding by young age.

Negative margins in BCS for DCIS have been shown to reduce the risk of local recurrence $(34,35)$, however, the optimal margin distance was debated until the publication of a large meta-analysis on margin width and local recurrence in 2016 (36). The metaanalysis based on 20 studies found that negative surgical margins after BCS halved the risk of ipsilateral breast recurrence compared to positive margins (OR $0.45,95 \%$ confidence intervals $0.30-0.62$ ) and that a margin wider than $2 \mathrm{~mm}$ did not further decrease the risk. Based on this meta-analysis consensus guidelines were published the same year establishing a margin of $2 \mathrm{~mm}$ as adequate among women with DCIS undergoing BCS+RT (37). The consensus guidelines state that negative margins narrower than $2 \mathrm{~mm}$ are not alone an indication for mastectomy, and that other factors known to affect rates of local recurrence also should be considered in decisions to re-excise. Recently published data from the UK Sloane national audit of screen-detected DCIS in 11,337 patients diagnosed 2003-2012 (38) showed involved margins in $3 \%$ and another $11 \%$ with a negative margin narrower than $2 \mathrm{~mm}$. In a large retrospective study including 3000 women treated with mastectomy for DCIS was margin status not significantly associated with risk of loco-regional recurrence (24).

Pathological features like large tumor extent, high nuclear grade, comedo necrosis and predominant architectural growth pattern have frequently but not consistently been associated with a higher risk of local recurrence (11,23,24,28,29,32,39-41). In women treated with BCS only, studies have shown a significant association between increasing tumor extent and risk of recurrence, but not in patients receiving $\mathrm{RT}(13,42)$.

High nuclear grade DCIS has been shown to be associated with a higher risk of invasive recurrence than low nuclear grade $(28,43)$, but loses significance with a longtime follow up $(43,44)$. Data suggest high grade lesions recur earlier, while low grade lesions "catch up" with a longer follow-up.

Surrogate molecular subtype of DCIS, based on the immunohistochemical expression of the biomarkers ER, progesterone receptor (PR) and HER2, has been shown to be an independent risk factor of recurrence overall and of invasive recurrence (45). Also, at longtime follow-up the highest risk of local recurrence was seen in HER2 type DCIS and the lowest in Luminal A DCIS (HR 6.46 for HER2 type DCIS compared to Luminal A DCIS), and the authors suggested routine HER2 testing of DCIS to better individualize treatment. These results are in accordance with studies indicating that certain biomarkers can be useful to predict risk of recurrence. Expression of HER2 and Ki67 have both been associated with a higher risk of recurrence, alone or in combination with other biomarkers $(29,46,47)$.

The Oncotype DX DCIS Score is a multigene assay for DCIS patients that includes 12 of the 21 genes included in the assay for invasive carcinoma. The DCIS Score was developed to predict risk of recurrence (DCIS or invasive) at 10 years following treatment by BCS alone and was independently validated in a prospective clinical trial and a population- 
based cohort $(48,49)$. The 10 -year risks for developing an ipsilateral breast recurrence in the prospective trial were $10.6 \%, 26.7 \%$, and $25.9 \%$ for the low-, intermediate-, and highrisk groups, respectively (log rank $\mathrm{p}=0.006$ ) (48) with corresponding rates of $12.7 \%, 33 \%$ and $27.8 \%$ for the low-, intermediate-, and high-risk groups in the population-based cohort (49). The 10-year rates for developing an invasive ipsilateral breast recurrence in the two studies were $3.7 \%, 12.3 \%$, and $19.2 \%$, respectively (log rank $\mathrm{p}=0.003$ ) and $8.0 \%$, $20.9 \%$, and $15.5 \%$, respectively. The DCIS Score has shown to be predictive of recurrence also in patients treated with BCS+RT (50). The test adds prognostic value also when used in combination with conventional clinical pathological features such as age, size, margin status, and multifocality. There is however yet a limited experience with regard to the clinical utility of the Oncotype Dx DCIS Score (51) and the assay was not designed to predict response to radiotherapy or endocrine therapy. Available data have failed to identify a subset of patients who do not benefit from radiotherapy.

\section{Treatment of Recurrence after Primary Treatment}

The medical evidence on optimal management of ipsilateral recurrence after a primary DCIS is weak. Few studies have analyzed the pattern of care in these patients $(22,52-54)$. Factors important for treatment decisions at time of recurrence is type (invasive or DCIS), recurrence extent, recurrence location, and prior treatment. The treatment strategy should be discussed in a multidisciplinary team. In case of invasive recurrence both initial metastatic work-up and neoadjuvant treatment should be considered.

The almost always invasive recurrences seen after mastectomy can be handled with wide local excision (55). Resection of muscle or part of the thoracic wall may be required. For patients previously treated with BCS+RT, mastectomy is still the standard procedure, but repeat-BCS could also be considered, especially in DCIS recurrence. For patients previously treated with BCS only, repeat-BCS $+\mathrm{RT}$ is the primary option if extent of disease allows for that.

In a recent large retrospective study based on the SEER registry, including 5344 patients with ipsilateral recurrence 1975-2016 after treatment for a primary DCIS $(47 \%$ of BCS patients had RT at primary treatment), the long-term survival after repeat-BCS versus mastectomy was compared (52). RepeatBCS was performed in $34 \%$ of the patients, and mastectomy in 66\%. After adjustment for confounders, no statistically significant difference in overall or disease-specific survival was observed (5-year overall survival: $87.0 \%$ versus $86.5 \%, \mathrm{P}=0.3$; breast cancer-specific survival: $96.7 \%$ versus $94.2 \%, \mathrm{P}=0.43$ ), and this was true both for invasive and in situ recurrences. Outcomes after repeat-BCS + RT was equal to mastectomy, and superior to repeat-BCS alone (52). Superiority of repeat$\mathrm{BCS}+\mathrm{RT}$ was significant in women aged 60 or more at time of recurrence, however only with a minimal gain in 5-year breast cancerspecific survival $(97.7 \%$ for repeat-BCS $+\mathrm{RT}$ versus $95.8 \%$ for repeat-BCS only, $\mathrm{p}=0.01$ ) (52).

In another recently published study based on the on 322 local recurrences after primary DCIS or invasive cancer operated with BCS+RT, $40 \%$ had repeat-BCS and 60\% mastectomy (54). There was a significant trend towards more repeat-BCS in recent years, increasing from $27 \%$ in $2000-2004$ to $61 \%$ in $2015-2019$. Breast cancer-specific and overall survival from primary treatment, as well as from local recurrence, were both comparable whether repeat-BCS or mastectomy was performed. Repeat-BCS should be considered an adequate choice of surgery in properly selected patients with favorable pathology and long disease-free interval.

In invasive recurrence an axillary staging procedure with a sentinel node biopsy is recommended. Even if previous axillary surgery or primary mastectomy has been performed, a sentinel node can be found in $50-60 \%$ which might add information in postoperative treatment decisions for systemic therapy and 
radiotherapy (56). In case of previous axillary surgery/mastectomy, an aberrant location of the sentinel node is not uncommon, i.e., outside of the ipsilateral axilla (56-59), and a preoperative lymphoscintigraphy increases detection rate.

In order to improve local control after radical salvage surgery for invasive recurrence, and decrease the risk of distant disease, systemic treatment as well as radiotherapy, should be offered if not previously given $(60,61)$. The medical evidence for re-irradiation is accumulating, although mainly from small retrospective studies, and can be considered in selected cases (62-68). Endocrine treatment for ER-positive invasive recurrences decreases the risk for a new local or distant recurrence with $10 \%$ and $21 \%$, respectively (69). Chemotherapy decreases the risk for recurrence and death by breast cancer in patients with isolated invasive recurrences irrespective of ER-status, but more pronounced in ER-negative disease (70).

\section{Prognosis after Local Recurrence}

Approximately $3-4 \%$ of women with DCIS will die of breast cancer within 20 years after diagnosis $(4,71)$ and a majority of them without a previous ipsilateral invasive recurrence $(3,4,71)$. It is not clear to what extent breast cancer mortality after DCIS is secondary to invasive recurrences and to what extent it is due to a high malignant potential associated with the primary disease. Women with in situ breast cancer are at increased risk of subsequent invasive breast cancer in both the ipsilateral and the contralateral breast compared to women in the general population $(4,72)$. A unilateral recurrence of DCIS, or a contralateral DCIS event, has no impact on mortality $(4,5,71,72)$, but an invasive cancer does. Experiencing an ipsilateral invasive recurrence after a primary DCIS increases the risk of breast cancer death 18 -fold while contralateral invasive disease increases the risk 13-fold (4). However, intense local treatment of DCIS to prevent local recurrences does not affect the risk of breast cancer death $(4,5,13)$.
In a retrospective study of more than 300000 women with stage I/II breast cancer disease-specific survival at 9 years was compared between those with a prior ipsilateral or contralateral DCIS ( $\mathrm{n}=5395$ women, breast cancer-specific survival 94.6\%) and those with no prior DCIS $(95.2 \%)(\mathrm{p}=0.32)$. In women with invasive recurrence after DCIS, the prognosis is comparable to that in women with primary early-stage invasive disease (73).

\section{Conclusion}

Patients with DCIS have an excellent longterm prognosis with a 10-year breast cancerspecific survival around 98\%. Treatment has the goal to prevent the development of an invasive breast cancer and to minimize the risk for a second breast cancer event with as little effect as possible on the patient's quality of life. Experiencing an ipsilateral invasive recurrence after a primary DCIS does significantly increase the risk of breast cancer death. More intensive local intervention at primary DCIS treatment offers a better long-term local control. Radical surgery remains crucial to minimize the risk of local recurrence, and adjuvant radiotherapy decreases the risk of local recurrence by at least $50 \%$. At recurrence, a repeat-BCS should be considered as it offers a good local control in properly selected patients and an overall and breast cancerspecific survival comparable to that seen after mastectomy.

\section{Conflict of Interest}

The authors declare no conflicts of interests.

\section{References}

1. Lynge E, Ponti A, James T, Majek O, von Euler-Chelpin M, Anttila A, et al. Variation in detection of ductal carcinoma in situ during screening mammography: a survey within the International Cancer Screening Network. Eur J Cancer. 2014;50(1):185-92.

2. Worni M, Akushevich I, Greenup R, Sarma D, Ryser MD, Myers ER, et al. Trends in Treatment Patterns and Outcomes for Ductal Carcinoma In Situ. J Natl Cancer Inst. 2015;107(12):djv263.

3. Elshof LE, Schmidt MK, Rutgers EJT, van Leeuwen FE, Wesseling J, Schaapveld M. Cause-specific Mortality in a Population-based Cohort of 9799 Women Treated for Ductal Carcinoma In Situ. Ann Surg. 2018; 267(5):952-8. 
4. Narod SA, Iqbal J, Giannakeas V, Sopik V, Sun P. Breast Cancer Mortality After a Diagnosis of Ductal Carcinoma In Situ. JAMA Oncol. 2015;1(7):88896.

5. Donker M, Litiere S, Werutsky G, Julien JP, Fentiman IS, Agresti R, et al. Breast-conserving treatment with or without radiotherapy in ductal carcinoma In Situ: 15-year recurrence rates and outcome after a recurrence, from the EORTC 10853 randomized phase III trial. J Clin Oncol. 2013;31(32): 4054-9.

6. Karlsson E, Sandelin K, Appelgren J, Zhou W, Jirstrom K, Bergh J, et al. Clonal alteration of breast cancer receptors between primary ducta carcinoma in situ (DCIS) and corresponding local events. Eur J Cancer. 2014;50(3):517-24

7. Gorringe KL, Hunter SM, Pang JM, Opeskin K, Hill P, Rowley SM, et al. Copy number analysis of ductal carcinoma in situ with and without recurrence. Mod Pathol. 2015;28(9):1174-84.

8. Waldman FM, DeVries S, Chew KL, Moore DH, 2nd, Kerlikowske K, Ljung BM. Chromosomal alterations in ductal carcinomas in situ and their in situ recurrences. J Natl Cancer Inst. 2000;92(4):313-20.

9. Yates LR, Knappskog S, Wedge D, Farmery JHR, Gonzalez S, Martincorena I, et al. Genomic Evolution of Breast Cancer Metastasis and Relapse. Cancer Cell. 2017;32(2):169-84 e7.

10. Wapnir IL, Dignam JJ, Fisher B, Mamounas EP, Anderson SJ, Julian TB, et al. Long-term outcomes of invasive ipsilateral breast tumor recurrences after lumpectomy in NSABP B-17 and B-24 randomized clinical trials for DCIS J Natl Cancer Inst. 2011;103(6):478-88.

11. Bijker N, Meijnen P, Peterse JL, Bogaerts J, Van Hoorebeeck I, Julien JP, et al. Breast-conserving treatment with or without radiotherapy in ducta carcinoma-in-situ: ten-year results of European Organisation for Research and Treatment of Cancer randomized phase III trial 10853--a study by the EORTC Breast Cancer Cooperative Group and EORTC Radiotherapy Group. J Clin Oncol. 2006;24(21):3381-7.

12. Houghton J, George WD, Cuzick J, Duggan C, Fentiman IS, Spittle M, et al. Radiotherapy and tamoxifen in women with completely excised ductal carcinoma in situ of the breast in the UK, Australia, and New Zealand: randomised controlled trial. Lancet. 2003;362(9378):95-102

13. Correa C, McGale P, Taylor C, Wang Y, Clarke M, Davies C, et al. Overview of the randomized trials of radiotherapy in ductal carcinoma in situ of the breast. J Natl Cancer Inst Monogr. 2010;2010(41):162-77.

14. Goodwin A, Parker S, Ghersi D, Wilcken N. Post-operative radiotherapy for ductal carcinoma in situ of the breast--a systematic review of the randomised trials. Breast. 2009;18(3):143-9.

15. Allred DC, Anderson SJ, Paik S, Wickerham DL, Nagtegaal ID, Swain SM, et al. Adjuvant tamoxifen reduces subsequent breast cancer in women with estrogen receptor-positive ductal carcinoma in situ: a study based on NSABP protocol B-24. J Clin Oncol. 2012;30(12):1268-73.

16. Yan Y, Zhang L, Tan L, Ma X, Zhang Y, Shao S, et al. Endocrine Therapy for Ductal Carcinoma In Situ (DCIS) of the Breast with Breast Conserving Surgery (BCS) and Radiotherapy (RT): a Meta-Analysis. Pathol Oncol Res. 2020;26(1):521-31.

17. Staley H, McCallum I, Bruce J. Postoperative Tamoxifen for ducta carcinoma in situ: Cochrane systematic review and meta-analysis. Breast. 2014:23(5):546-51.

18. Stuart KE, Houssami N, Taylor R, Hayen A, Boyages J. Long-term outcomes of ductal carcinoma in situ of the breast: a systematic review, meta-analysis and meta-regression analysis. BMC Cancer. 2015;15:890

19. Elshof LE, Schaapveld M, Schmidt MK, Rutgers EJ, van Leeuwen FE, Wesseling J. Subsequent risk of ipsilateral and contralateral invasive breas cancer after treatment for ductal carcinoma in situ: incidence and the effect of radiotherapy in a population-based cohort of 10,090 women. Breast Cancer Res Treat. 2016;159(3):553-63.

20. Subhedar P, Olcese C, Patil S, Morrow M, Van Zee KJ. Decreasing Recurrence Rates for Ductal Carcinoma In Situ: Analysis of 2996 Women Treated with Breast-Conserving Surgery Over 30 Years. Ann Surg Oncol. 2015;22(10):3273-81

21. Halasz LM, Sreedhara M, Chen YH, Bellon JR, Punglia RS, Wong JS, et al Improved outcomes of breast-conserving therapy for patients with ductal carcinoma in situ. Int J Radiat Oncol Biol Phys. 2012;82(4):e581-6.
22. Greenberg CC, Habel LA, Hughes ME, Nekhlyudov L, Achacoso N, Acton L, et al. Characterization and treatment of local recurrence following breast conservation for ductal carcinoma in situ. Ann Surg Oncol. 2014;21(12): 3766-73.

23. Collins LC, Achacoso N, Haque R, Nekhlyudov L, Fletcher SW, Quesenberry $\mathrm{CP}$, Jr., et al. Risk factors for non-invasive and invasive local recurrence in patients with ductal carcinoma in situ. Breast Cancer Res Treat. 2013; 139(2):453-60.

24. Mamtani A, Nakhlis F, Downs-Canner S, Zabor EC, Morrow M, King TA, et al. Impact of Age on Locoregional and Distant Recurrence After Mastectomy for Ductal Carcinoma In Situ With or Without Microinvasion. Ann Surg Oncol. 2019;26(13):4264-71.

25. Owen D, Tyldesley S, Alexander C, Speers C, Truong P, Nichol A, et al. Outcomes in patients treated with mastectomy for ductal carcinoma in situ. Int J Radiat Oncol Biol Phys. 2013;85(3):e129-34.

26. Pawloski KR, Tadros AB, Sevilimedu V, Newman A, Gentile L, Zabor EC, et al. Patterns of invasive recurrence among patients originally treated for ductal carcinoma in situ by breast-conserving surgery versus mastectomy. Breast Cancer Res Treat. 2021;186(3):617-24.

27. Benson JR, Wishart GC. Predictors of recurrence for ductal carcinoma in situ after breast-conserving surgery. Lancet Oncol. 2013;14(9):e348-57.

28. Kerlikowske K, Molinaro A, Cha I, Ljung BM, Ernster VL, Stewart K, et al. Characteristics associated with recurrence among women with ductal carcinoma in situ treated by lumpectomy. J Natl Cancer Inst. 2003;95(22): 1692-702.

29. Kerlikowske K, Molinaro AM, Gauthier ML, Berman HK, Waldman F, Bennington J, et al. Biomarker expression and risk of subsequent tumors after initial ductal carcinoma in situ diagnosis. J Natl Cancer Inst. 2010; 102(9):627-37

30. Warnberg F, Garmo H, Emdin S, Hedberg V, Adwall L, Sandelin K, et al. Effect of radiotherapy after breast-conserving surgery for ductal carcinoma in situ: 20 years follow-up in the randomized SweDCIS Trial. J Clin Oncol. 2014;32(32):3613-8.

31. Cronin PA, Olcese C, Patil S, Morrow M, Van Zee KJ. Impact of Age on Risk of Recurrence of Ductal Carcinoma In Situ: Outcomes of 2996 Women Treated with Breast-Conserving Surgery Over 30 Years. Ann Surg Oncol. 2016;23(9):2816-24.

32. Alvarado R, Lari SA, Roses RE, Smith BD, Yang W, Mittendorf EA, et al. Biology, treatment, and outcome in very young and older women with DCIS. Ann Surg Oncol. 2012;19(12):3777-84.

33. Rudloff U, Brogi E, Reiner AS, Goldberg JI, Brockway JP, Wynveen CA, et al. The influence of margin width and volume of disease near margin on benefit of radiation therapy for women with DCIS treated with breastconserving therapy. Ann Surg. 2010;251(4):583-91.

34. Wang SY, Chu H, Shamliyan T, Jalal H, Kuntz KM, Kane RL, et al. Network meta-analysis of margin threshold for women with ductal carcinoma in situ. J Natl Cancer Inst. 2012:104(7):507-16.

35. Dunne C, Burke JP, Morrow M, Kell MR. Effect of margin status on local recurrence after breast conservation and radiation therapy for ductal carcinoma in situ. J Clin Oncol. 2009;27(10):1615-20.

36. Marinovich ML, Azizi L, Macaskill P, Irwig L, Morrow M, Solin LJ, et al. The Association of Surgical Margins and Local Recurrence in Women with Ductal Carcinoma In Situ Treated with Breast-Conserving Therapy: A MetaAnalysis. Ann Surg Oncol. 2016;23(12):3811-21.

37. Morrow M, Van Zee KJ, Solin LJ, Houssami N, Chavez-MacGregor M, Harris $J R$, et al. Society of Surgical Oncology-American Society for Radiation Oncology-American Society of Clinical Oncology Consensus Guideline on Margins for Breast-Conserving Surgery with Whole-Breast Irradiation in Ductal Carcinoma In Situ. Ann Surg Oncol. 2016;23(12):3801-10.

38. Shaaban AM, Hilton B, Clements K, Provenzano E, Cheung S, Wallis MG, et al. Pathological features of 11,337 patients with primary ductal carcinoma in situ (DCIS) and subsequent events: results from the UK Sloane Project. $\mathrm{Br}$ J Cancer. 2021;124(5):1009-17.

39. Fisher ER, Dignam J, Tan-Chiu E, Costantino J, Fisher B, Paik S, et al. Pathologic findings from the National Surgical Adjuvant Breast Project (NSABP) eight-year update of Protocol B-17: intraductal carcinoma. Cancer. 1999:86(3):429-38. 
40. Pinder SE, Duggan C, Ellis IO, Cuzick J, Forbes JF, Bishop H, et al. A new pathological system for grading DCIS with improved prediction of local recurrence: results from the UKCCCR/ANZ DCIS trial. Br J Cancer. 2010; 103(1):94-100.

41. Groen EJ, Hudecek J, Mulder L, van Seijen M, Almekinders MM, Alexov S, et al. Prognostic value of histopathological DCIS features in a large-scale international interrater reliability study. Breast Cancer Res Treat. 2020; 183(3):759-70

42. Solin LJ, Gray R, Hughes LL, Wood WC, Lowen MA, Badve SS, et al. Surgical Excision Without Radiation for Ductal Carcinoma in Situ of the Breast: 12-Year Results From the ECOG-ACRIN E5194 Study. J Clin Oncol. 2015;33(33):3938-44.

43. Wallis MG, Clements K, Kearins 0 , Ball G, Macartney J, Lawrence GM. The effect of DCIS grade on rate, type and time to recurrence after 15 years of follow-up of screen-detected DCIS. Br J Cancer. 2012;106(10):1611-7.

44. Solin LJ, Kurtz J, Fourquet A, Amalric R, Recht A, Bornstein BA et al. Fifteen-year results of breast conserving surgery and definitive breast irradiation for the treatment of ductal carcinoma in situ of the breast. J Clin Oncol 1996; 14: 754-63.

45. Williams KE, Barnes NLP, Cramer A, Johnson R, Cheema K, Morris J, et al. Molecular phenotypes of DCIS predict overall and invasive recurrence. Ann Oncol. 2015;26(5):1019-25.

46. Han K, Nofech-Mozes S, Narod S, Hanna W, Vesprini D, Saskin R, et al. Expression of HER2neu in ductal carcinoma in situ is associated with local recurrence. Clin Oncol (R Coll Radiol). 2012;24(3):183-9.

47. Rakovitch E, Nofech-Mozes S, Hanna W, Narod S, Thiruchelvam D, Saskin $\mathrm{R}$, et al. HER2/neu and Ki-67 expression predict non-invasive recurrence following breast-conserving therapy for ductal carcinoma in situ. $\mathrm{Br} \mathrm{J}$ Cancer. 2012;106(6):1160-5.

48. Solin LJ, Gray R, Baehner FL, Butler SM, Hughes LL, Yoshizawa C,et al. A multigene expression assay to predict local recurrence risk for ductal carcinoma in situ of the breast. J Natl Cancer Inst. 2013;105(10):701-10.

49. Rakovitch E, Nofech-Mozes S, Hanna W, Baehner FL, Saskin R, Butler SM, et al. A population-based validation study of the DCIS Score predicting recurrence risk in individuals treated by breast-conserving surgery alone. Breast Cancer Res Treat. 2015;152(2):389-98.

50. Rakovitch E, Nofech-Mozes S, Hanna W, Sutradhar R, Baehner FL, Miller DP, et al. Multigene Expression Assay and Benefit of Radiotherapy After Breast Conservation in Ductal Carcinoma in Situ. J Natl Cancer Inst. 2017; 109(4)):djw256.

51. Nofech-Mozes S, Hanna W, Rakovitch E. Molecular Evaluation of Breast Ductal Carcinoma in Situ with Oncotype DX DCIS. Am J Pathol. 2019; 189(5):975-80

52. Li Q, Wang K, Yang L, Wu Q, Zhu W, Li Z, et al. Long-term Survival Comparison of Repeated Breast-conserving Surgery Versus Mastectomy for Patients with DCIS with Ipsilateral Breast Tumor Recurrence: A Real-world Longitudinal Study. Clin Breast Cancer. 2021;21(4):360-372

53. Hassett MJ, Jiang W, Hughes ME, Edge S, Javid SH, Niland JC, et al. Treating Second Breast Events After Breast-Conserving Surgery for Ductal Carcinoma in Situ. J Natl Compr Canc Netw. 2018;16(4):387-94.

54. Van den Bruele AB, Chen I, Sevilimedu V, Le T, Morrow M, Braunstein LZ, et al. Management of ipsilateral breast tumor recurrence following breast conservation surgery: a comparative study of re-conservation vs mastectomy. Breast Cancer Res Treat. 2021;187(1):105-12.

55. Kuo SH, Huang CS, Kuo WH, Cheng AL, Chang KJ, Chia-Hsien Cheng J. Comprehensive locoregional treatment and systemic therapy for postmastectomy isolated locoregional recurrence. International journal of radiation oncology, biology, physics. 2008;72(5):1456-64.

56. Ahmed M, Baker R, Rubio IT. Meta-analysis of aberrant lymphatic drainage in recurrent breast cancer. The British journal of surgery. 2016;103(12): 1579-88.

57. Vugts G, Maaskant-Braat AJ, Voogd AC, van Riet YE, Luiten EJ, Rutgers EJ, et al. Repeat sentinel node biopsy should be considered in patients with locally recurrent breast cancer. Breast cancer research and treatment. 2015;153(3):549-56.

58. Maaskant-Braat AJ, Roumen RM, Voogd AC, Pijpers R, Luiten EJ, Rutgers
EJ, et al. Sentinel Node and Recurrent Breast Cancer (SNARB): results of a nationwide registration study. Annals of surgical oncology. 2013; 20(2):620-6.

59. Maaskant-Braat AJ, Voogd AC, Roumen RM, Nieuwenhuijzen GA. Repeat sentinel node biopsy in patients with locally recurrent breast cancer: a systematic review and meta-analysis of the literature. Breast cancer research and treatment. 2013;138(1):13-20.

60. Wong SM, Golshan M. Management of In-Breast Tumor Recurrence. Annals of surgical oncology. 2018;25(10):2846-51.

61. Halverson KJ, Perez CA, Kuske RR, Garcia DM, Simpson JR, Fineberg B. Isolated local-regional recurrence of breast cancer following mastectomy: radiotherapeutic management. International journal of radiation oncology, biology, physics. 1990;19(4):851-8.

62. Arthur DW, Winter KA, Kuerer HM, Haffty B, Cuttino L, Todor DA, et al. Effectiveness of Breast-Conserving Surgery and 3-Dimensional Conformal Partial Breast Reirradiation for Recurrence of Breast Cancer in the Ipsilateral Breast: The NRG Oncology/RTOG 1014 Phase 2 Clinical Trial. JAMA Oncol. 2020;6(1):75-82.

63. Walstra C, Schipper RJ, Poodt IGM, van Riet YE, Voogd AC, van der Sangen MJC, et al. Repeat breast-conserving therapy for ipsilateral breast cancer recurrence: A systematic review. Eur J Surg Oncol. 2019:45(8):1317-27.

64. Hannoun-Levi JM, Houvenaeghel G, Ellis S, Teissier E, Alzieu C, Lallement $M$, et al. Partial breast irradiation as second conservative treatment for local breast cancer recurrence. International journal of radiation oncology, biology, physics. 2004;60(5):1385-92.

65. Sedlmayer F, Zehentmayr F, Fastner G. Partial breast re-irradiation for local recurrence of breast carcinoma: Benefit and long term side effects. Breast. 2013;22 Suppl 2:S141-6.

66. Hannoun-Levi JM, Resch A, Gal J, Kauer-Dorner D, Strnad V, Niehoff P, et al. Accelerated partial breast irradiation with interstitial brachytherapy as second conservative treatment for ipsilateral breast tumour recurrence: multicentric study of the GEC-ESTRO Breast Cancer Working Group. Radiotherapy and oncology : journal of the European Society for Therapeutic Radiology and Oncology. 2013;108(2):226-31.

67. Trombetta M, Hall M, Julian TB. Long-term followup of breast preservation by re-excision and balloon brachytherapy after ipsilateral breast tumor recurrence. Brachytherapy. 2014;13(5):488-92.

68. Arthur DW, Winter KA, Kuerer HM, Haffty BG, Cuttino LW, Todor DA, et al. NRG Oncology-Radiation Therapy Oncology Group Study 1014: 1-Year Toxicity Report From a Phase 2 Study of Repeat Breast-Preserving Surgery and 3-Dimensional Conformal Partial-Breast Reirradiation for In-Breast Recurrence. International journal of radiation oncology, biology, physics. 2017:98(5):1028-35.

69. Waeber M, Castiglione-Gertsch M, Dietrich D, Thurlimann B, Goldhirsch A, Brunner $\mathrm{KW}$, et al. Adjuvant therapy after excision and radiation of isolated postmastectomy locoregional breast cancer recurrence: definitive results of a phase III randomized trial (SAKK 23/82) comparing tamoxifen with observation. Annals of oncology : official journal of the European Society for Medical Oncology / ESM0. 2003;14(8):1215-21.

70. Aebi S, Gelber, S., Láng, I., Anderson, S.J., Robidoux, A., Martin, M., et al. Chemotherapy prolongs survival for isolated local or regional recurrence of breast cncer: The CALOR trial (Chemotherapy as Adjuvant for Locally Recurrent breast cancer; IBCSG 27-02, NSABP B-37, BIG 1-02). Cancer Research. 2012;72(24).

71. Wärnberg F, Garmo H, Emdin S, Hedberg V, Adwall L, Sandelin K, et al. Effect of radiotherapy after breast-conserving surgery for ductal carcinoma in situ: 20 years follow-up in the randomized SweDCIS trial. J Clin Oncol. 2014;32(32):3613-8

72. Sackey H, Hui M, Czene K, Verkooijen H, Edgren G, Frisell J, et al. The impact of in situ breast cancer and family history on risk of subsequent breast cancer events and mortality -a population-based study from Sweden. Breast Cancer Research.2016;18:10573.

73. Sopik V, Iqbal J, Sun P, Narod SA.Impact of a prior diagnosis of DCIS on survival from invasive breast cancer. Breast cancer research and treatment. 2016;158(2):385-93. 